\title{
（1）土木・森林環境研究小委員会 活動報告
}

土木森林環境研究小委員会

司代 明*

Akira SHIDAI

1. 小委員会の活動計画

名称：土木・森林環境研究小委員会

研究の背景 : 地球規模での森林の減少・消失（熱帯林の減少、砂漠化の進行、北方林の破壊など）

国内の森林における問題（里山の荒廃、人工林の管理不備、森林経営の行き詰まりなど）

森林の機能の見直し（ＣＯＰ３：二酸化炭素吸収源としての森林の役割に注目）

森林をできるだけ保全した開発の要求（「自然環境と共生する開発」概念の導入・展開）

活 動 目的：土木界における森林に関する基礎的な知識の習得・把握、共生の概念の認識、森林の二酸化

炭素吸収能の定量的評価、森林の環境保全機能を生かした国土計画・都市計画手法の新たな

展開等

活動計画：○研究会（森林と国土・環境保全に関する研究会）の開催

第 1 回 世界及び日本の森林の現状と問題点（平成10年11月開催）

講師：小澤 普照氏；（財）林政総合研究所

高橋 邦秀氏; 北海道大学大学院

第 2 回 森林生態系の構造と機能（平成11年 1 月開催）

講師 : 只木 良也氏 ; プレック研究所

亀山 章氏 : 東京農工大学

第 3 回 地球環境と森林 (平成11年 4 月開催)

講師：垰田 宏氏;林野庁森林総合研究所

高橋 正通氏; 林野庁森林総合研究所

第 4 回 森林と水環境 一森林の水環境調節機能と河川流域の管理一

第 5 回 森林と土㙥環境 一森林の土壌環境保全機能一

第 6 回 森林と都市環境 一都市内森林の機能一

○研究会成果のとりまとめならびに地球環境シンポジウム等における発表

○報告書「土木·森林環境研究」の作成

2. 小委員会において着目している森林の機能

○公益的機能：水源涵盖、土砂流出・崩壊防止、野生鳥獣保護、酸素供給·大気浄化、騒意防 歨、気候緩和、保健休養等

○炭素プール機能 : 生きた植物体、倒木等、泥炭及び土壌炭素としてのバイオマス蓄積機能

○林産物の生産機能

注）アンダーラインはこの研究会でとくに着目している機能

*東京電力株式会社環境部 Environment Department, Tokyo Electric Power Co. Inc. 
3.1 世界及び日本の森林の現状と問題点

（A）世界及び日本の森林資源

地球全体の森林は約34億haで、陸地面積（約 130億ha)の $27 \%$ 占めている。このうち、日本の 森林は0.25億haで、世界全体の森林面積の0.7\% である。

幹の蓄積量は約 3,840 億立方メートルと推定さ れ、森林生態系内に蓄積されている炭素量は陸上 生態系の 6 〜 割を占めている。

\section{表一 1 日本の森林資源}

\begin{tabular}{|c|c|c|c|c|c|}
\hline & & 国有林 & 公有林 & 私有林 & 総計 \\
\hline \multirow[t]{4}{*}{ 面積 } & 人工林 & 2,446 & 1,209 & 6,743 & 10,398 \\
\hline & 天然林 & 4,738 & 1,433 & 7,211 & 13,382 \\
\hline & 無立木地 & 660 & 83 & 471 & 1,214 \\
\hline & 小計 & 7,844 & 2,725 & 14,425 & 24,994 \\
\hline \multirow[t]{3}{*}{ 蓄積 } & $\begin{array}{l}\text { 人工林 } \\
\text { 天然林 }\end{array}$ & $\begin{array}{l}29,223 \\
61,871\end{array}$ & $\begin{array}{l}19,859 \\
16,042\end{array}$ & $\begin{array}{r}140,117 \\
81,089\end{array}$ & $\begin{array}{l}189,199 \\
159,002\end{array}$ \\
\hline & 無立木地 & 113 & 6 & 4 & 123 \\
\hline & 小計 & 91,207 & 35,907 & 221,210 & 348,324 \\
\hline
\end{tabular}

表一2 世界の森林資源

\begin{tabular}{|c|c|c|c|c|c|c|c|c|}
\hline 地域区分 & 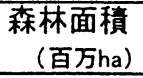 & $\begin{array}{r}\text { 森林率 } \\
(\%) \\
\end{array}$ & $\begin{array}{l}\text { 森林蓄積 } \\
\text { (百万m } 3 \text { ) * }\end{array}$ & $\begin{array}{c}\text { 現存量 } \\
\text { (百万トン) * }\end{array}$ & $\begin{array}{l}\text { 木材生産量 } \\
\text { (百万的3)** }\end{array}$ & $\begin{array}{c}\text { 用材 } \\
(\text { 百万到 } 3 \text { ) ** }\end{array}$ & $\begin{array}{c}\text { 薪炭材 } \\
\text { (百万 } \mathrm{m} 3 \text { ) ** }\end{array}$ & $\begin{array}{c}\text { 針葉樹 } \\
(\text { 百万的3) ** }\end{array}$ \\
\hline アフリカ & 520.2 & 17.6 & 55655 & 72306 & 567.1 & 64.8 & 502.4 & 19.7 \\
\hline アジア & 474.2 & 15.4 & 51634 & 69258 & 1137.7 & 259.1 & 878.6 & 195.9 \\
\hline ロシア & 763.5 & 45.2 & 84234 & 51648 & 484.2 & 100.1 & 33.4 & 163.5 \\
\hline ヨーロッパ & 169.8 & 29.7 & 19264 & 11864 & 350.7 & 297.1 & 53.6 & 76.4 \\
\hline 北アメリカ & 457.1 & 24.9 & 53401 & 44948 & 684.3 & 585.1 & 99.2 & 475.0 \\
\hline 中央アメリカ & 79.4 & 30.0 & 4067 & 7042 & 69.8 & 10.2 & 59.6 & 22.6 \\
\hline 南アメリカ & 870.6 & 49.7 & 105359 & 173265 & 382.6 & 126.5 & 256.1 & 77.3 \\
\hline オセアニア & 90.7 & 10.7 & 10119 & 10148 & 48.5 & 39.7 & 8.8 & 26.3 \\
\hline 世界 計 & 3454.4 & 26.5 & 383733 & 440479 & 3374.1 & 1482.5 & 1922.6 & 1124.8 \\
\hline
\end{tabular}

（B）森林の公益的機能の経済的価值

日本の森林が果たしている公益的機能（水源涵養、土砂流出・崩壊防止、保健休養、野生鳥獣保護、酸素 供給・大気浄化）の経済的価值は、約 39 兆円（平成 3 年、林野庁試算）

（C）森林保全と持続可能な森林経営のための国際的基準・指標

世界の森林保全と持続可能な経営を考えていく上で、国際的基準・指標が採択されている（モントリオー ル・プロセス,1995)。

国際基準 : (1)生物多様性の保全、(2)森林生態系の生産力の維持、(3)森林生態系の健全性と活力の維持、

(4)土潩及び水資源の保全と維持、(5)地球的炭素循環への森林の寄与の維持、〔6社会の要望を満 たす長期的・多面的な社会・経済的便益の維持及び増進、⑦森林の保全と持続可能な経営のた めの法的、制度的及び経済的枠組み

（D）日本の森林管理（経営）の問題点と解決に向けた方策

森林管理水準の低下 : 木材輸入量の增加、木材価格の低下、収益性の低下、林業就業者の減少・高齢化 高い労働災害 : 傾斜地等不利な労働環境

林業の経営環境の悪化：小規模、零細、林業生産活動の停滞

問題点打開方策 : 上下流一体的な連携、地方公共団体の一層の参画、国有林経営の改革などの総合的な政 策ならびに地球環境問題を視野に入れた施策の展開 


\section{2 森林生態系の構造と機能}

(A) 生態系と物質循環

生 態 系：あるまとまった空間に生活する生物のすべてと、その生育空間を満たす無機的（非生物的）環 境がなす系

物質循環 : 周囲の環境から太陽エネルギーと無機物を取り入れて光合成によって有機物を合成する植物

（生産者）、植物の生産物に依存して生活する動物（消費者）、生物遺体を分解し無機化して環 境へ還元する微生物（分解・還元者）、このようなエネルギーの流れと物質の循環的な動き

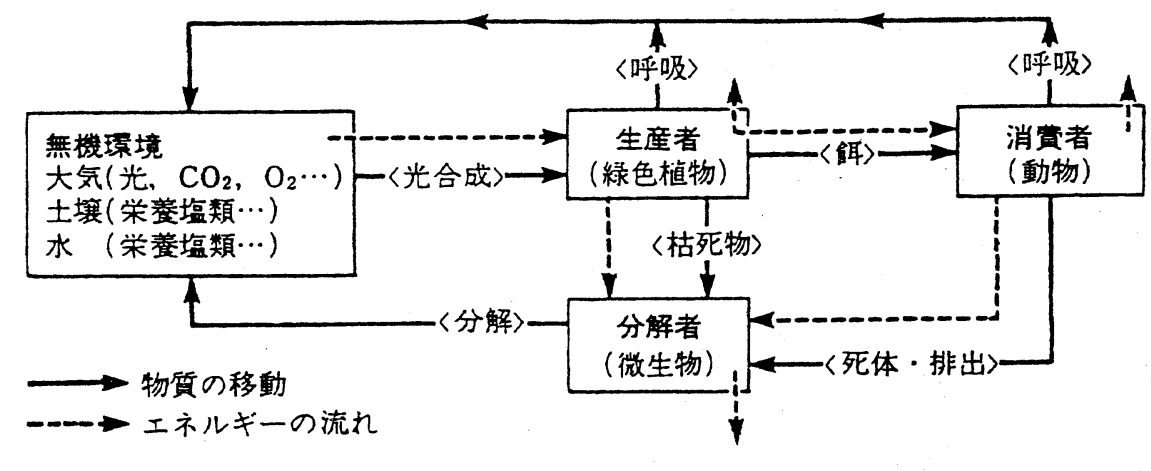

図ー1 生態系のエネルギーの流れと物質循環（蜂谷 1970、一部改変）

(B) 森林生態系

エネルギーの流れと物質循環が比較的完全で典型的、大規模かつ円滑に行われている場

大きな立体的空間に階層構造（植物の上下住み分け）が発達し、大きな有機物生産力を有している

(C) 森林生態系の維持条件

(1)太陽エネルギーの供給が十分であること

(2)その生態系が成立可能な環境条件が満足されていること

(3)生物相が豊富で互いに補いあうこと（生物種の多様性）

(4)多様な生物の生物量がそれぞれ適正であること

(5)生物と環境とのバランス

(D) 生態系に配慮した土木技術の展開例

エコロード（生き物にやさしい道路づくり）を例として

環境の均一化（従来技術）から環境の多様化（生態配慮技術）へ

例：生き物の生育環境（ビオトープ）の保全、創出、造成

生き物の時間（採䬲、休息、移動、繁殖、成長、死亡等の生活や生命現象の進行時間）への配慮

3. 3 地球環境と森林

(A) 森林の二酸化炭素吸収と貯留量の代表的算定法

積み上げ法：木材の伐採量と森林蓄積量の増減から算定

計算根拠が明確だが第三者の検証が困難。森林統計の精度次第

面積一係数法 : 森林面積と係数による推定

第三者の検証が可能だが適切な森林区分が必要。森林統計の精度次第

I P C C（気候変動に関する政府間パネル）のガイドラインに示されている方法 
（B）森林の炭素貯蔵量と森林土猿

全地球の森林中の炭素量 : 3,300 億 Cトン（森林バイオマス中） $+6,600$ 億 Cトン（森林土壌中）

陸上生態系に蓄えられている炭素のうち、40\%は森林土壌中に蓄えられている。

「気候変動に関する国際連合枠組み条約」に基づく第 2 回日本国報告書として1997年に報告された数值 を模式的に表したものを図一 2 に示す。

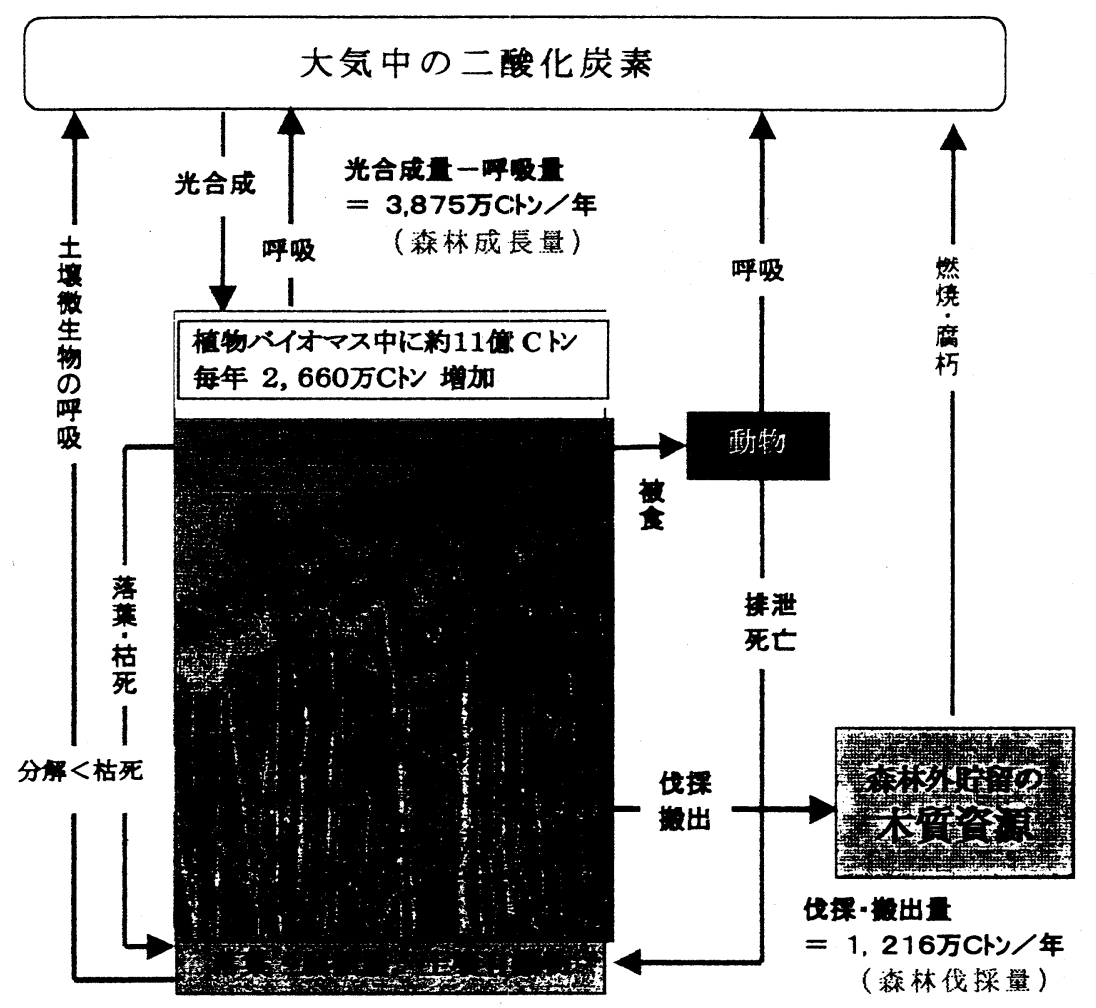

図ー2＼cjkstart森林生態系の炭素の流れ（数值は炭素換算量 : Cトン）

（C）地球的炭素循環への森林の寄与を維持かつ増大していくための原則

(1)環境悪化から森林を守る

(2)適地適木の原則を守る

(3)土袞の保全に努める

(4)葉量を常に最大に保つ

(5)生産林では適切な施業を実施する

6自然林の保護を徹底する

(7)森林に関する研究を推進する

3. 4 森林と水環境 一森林の水環境調節機能と河川流域の管理一

・森林の水源涵養機能と治水、利水を通した流域管理

・森林の水質保全機能と流域の水環境管理 
3. 5 森林と土㙥環境 一森林の土㙥環境保全機能一

・表土の供給源としての森林の機能

・森林と国土保全（土壊劣化、流動、砂漠化など）

・砂漠の緑化とその波及効果

3. 6 森林と都市環境 一都市内森林の機能一

・都市における林地の規模と期待される効果

・都市林の環境保全・アメニティ向上の定量的評価

4. 今後の活動計画

○森林と土木との関わりに着目した新たな土木学のテーマ発掘

○研究分科会創設ならびに研究学習の場の提供 